Vol. 1, No. 2

Vitoria - ES, Jun - Dec. 2004

DOI: http://dx.doi.org/10.15728/bbr.2004.1.2.3

p. $103-117$

\title{
Bonus pack promotions: Perceptions of Controllers and Commercial Managers
}

\author{
Reinaldo Guerreiro
}

University of São Paulo

\author{
Beng Soo Ong \\ California State University
}

\author{
Ariovaldo dos Santos \\ University of São Paulo
}

\begin{abstract}
This paper compares the perceptions of controllers with those of commercial managers in industrial companies with respect to various aspects of bonus packs promotions. The study is conducted on the premise that the economic result of a price discount decision and that of a product quantity bonus decision are equal (when considering the same product quantity delivered to the client). This study uses data from two independent studies. In the first, 600 questionnaires were sent to commercial managers in companies selected from different sectors and registered in the database of FIPECAFI-FEA-USP. In the second study, the same 600 questionnaires were sent to the controllers of the companies. The results demonstrate that the controllers and the commercial managers hold similar views with respect to the majority of the research questions. The points on which opinions differ refer to the calculation of the product cost and the cost of product bonus units for the company.
\end{abstract}

Key words: price discount, bonus packs, sales promotions.

Reinaldo Guerreiro

Doutorado em Controladoria e Contabilidade

Universidade de São Paulo

Adress: Av. Prof. Luciano Gualberto, 908 -

Prédo III, Cidade Universitária, 05508900 -

Sao Paulo, SP - Brazil

Email: reiguerr@usp.br

(11) 30915950
Beng Soo Ong

California State University

Email: atendimento@fucape.br
Ariovaldo dos Santos

Doutorado em Controladoria e Contabilidade

Universidade de São Paulo

Adress: Av. Prof. Luciano Gualberto, 908 -

Prédo III, Cidade Universitária, 05508900 -

Sao Paulo, SP - Brazil

Email: arisanto@usp.br

(11) 30915820 


\section{INTRODUCTION}

he bonus packs technique is one of a number of sales-promotion techniques. This

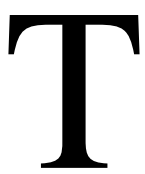
technique is common in big Brazilian companies that act as product suppliers for the retail sector, notably in the pharmaceutical industry, although various other sectors also use this policy (including the food industry and the cleaning products industry). The technique involves the purchaser paying for a certain number of units but receiving a higher number.

The premise of this study is that the economic result of a sales price discount decision and a product quantity bonus decision are intrinsically equal when considering the same product quantity delivered to the client. The objective of the study is to compare the perceptions of controllers with those of commercial managers in industrial companies with respect to various aspects of bonus packs decisions. In this context, various questions arise:

- Which company area decides about price discount or quantity discount?

- What are the main motives for the company to use quantity bonus instead of price discount (from the perspective of the controllers and commercial managers)?

- Which main objectives does the company try to reach by the bonus pack policy (according to the controllers and commercial managers)?

- What are the main negative points of a bonus pack policy (as reported by the controllers and commercial managers)?

- How does the company calculate the cost of its products (according to these managers)?

- How do the controllers and commercial managers evaluate the cost of the bonus units for the company?

- How do the controllers and commercial managers believe the client evaluates the economic benefit of the bonus units?

\section{LITERATURE REVIEW}

The literature review of the present study has identified many studies that consider various aspects of pricing policies and sales promotion, including those of Reiter (1994), Ong, Ho and Tripp (1997), Farhamgmher and Brito (1997), Siebert (1997), Friedman and Lewis (1999), Johnson et al. (1999), Kass (1999), Kopalle et al. (1999), Smith e Sinha (2000), Gurnani (2001), Arcelus et al. (2001), Monroe and Cox (2001), Munger and Grewal (2001), Guerreiro et al.(2004). However, few studies focusing on product quantity bonus issue was identified. The work by Ong, Ho and Tripp (1997), dealt with this issue on the basis of the perception of the final beneficiaries of the bonus packs policy and the work by Guerreiro et al. (2004) focused on the cost implications of bonus packs and price discounts promotions, according the point of view of commercial managers of industrial companies. The present study aims to expand the work of Guerreiro et al.(2004) adding new findings on this issue by comparing the perceptions of controllers and commercial managers in industrial companies.

\section{PRODUCT PROFITABILITY ANALYSIS}

Various authors in the field of cost accounting and management accounting, including Noreen, Smith and Mackey (1995), have demonstrated that, in view of the existence of restrictive production factors, every analysis and decision-making process involving product profitability must be founded on information based on the variable costing method, with the use of the contribution margin concept. Martins (1998) emphasized that, given limiting production factors, the conceptual basis of cost accounting in the making of profitability 
decisions is made up of the concepts of: (i) variable costing; (ii) product contribution margin; (iii) contribution margin of lines and divisions; and (iv) contribution margin. Horngren (1972) has put forward a solid argument on the advantage of variable costing and the contribution margin concept in relation to absorption costing. Goldratt's work (1992) presents a logical criticism of the absorption costing method and the activity-based costing method, as well criticizing the total product cost concept. The idealized theory of constraints emphasizes the administration of constraints as well as the application of the throughput concept-which actually corresponds to the contribution margin concept.

Guerreiro and Angelo (1999) have presented a price decision and profitability analysis model. This process is made operational on the basis of the concepts of variable costing and contribution margin. From the application of these concepts, a profit equation can be established which is valid for any business enterprise:

$$
\begin{aligned}
& r t-c t=r e \\
& r t-c v t-c f t=r e \\
& q v \cdot p v u-q \cdot c v u-c f t=r e \\
& q v \cdot p v u-q \cdot c v u=c f t+r e \\
& q v \cdot(p v u-c v u)=c f t+r e \\
& q v \cdot m c u=c f t+r e \\
& m c t=c f t+r e
\end{aligned}
$$

where:

$$
\begin{aligned}
& r e=\text { company income; } \\
& r t=\text { total revenue; } \\
& c t=\text { total cost; } \\
& c v t=\text { total variable cost; } \\
& c f t=\text { total fixed cost; } \\
& q v=\text { produced/sold quantity; } \\
& p v u=\text { product unit sales price; } \\
& c v u=\text { product unit variable cost } \\
& m c u=\text { product unit contribution margin; and } \\
& m c t=\text { total contribution margin. }
\end{aligned}
$$

The profit equation demonstrates the logic of the profitability decision model, whose objective can be expressed in terms of optimization of the company's global profit, through the optimization of the product contribution margin and the establishment of the optimal fixed cost structure of the company.

In this way, any decision made on the product level, which does not exert influence on the company's fixed cost structure, must be oriented by the rule of optimizing the total contribution margin of the products.

An important inference from these reflections is that the cost that can be directly allocated to the product is made up only from the variable costs. The company's fixed cost is always a periodical cost, which is global and linked to its structure in this period. As such, it is not directly related to the product units (which are neither sold nor receive a bonus) and it does not exert any influence on the specific decisions that surround product profitability (and do not therefore imply any change in the installed plant). The bonus decisions related to product quantity involve the delivery of physical product units without charge for the clients. The cost of the bonus product is always the variable cost. 


\section{PRICE DISCOUNT PERCENTAGE COMPARED WITH QUANTITY BONUS PERCENTAGE}

In principle, the result of a product quantity bonus decision might seem to be more profitable than the result of a sales price discount - because the cost of the bonus product corresponds only to its variable cost. Actually, it can be demonstrated that the results of product bonus and sales price discount decisions are exactly equal under certain conditions. The comparison of the economic result of price discount and product quantity bonus decisions must be oriented by the following basic premise - that the same quantity is delivered to the client in both decisions.

The price discount percentage and the product quantity bonus percentage must be economically equivalent. The usual product quantity bonus forms are expressed either in: (i) physical quantities (as, for example, if a company sells 100 product units and delivers 140); or (ii) in percentage terms (as, for example, if a company delivers a certain percentage on top of the quantity that was actually purchased, such as $40 \%$ extra units). For the correct calculation of the bonus percentage in the same economic terms as the price discount, the bonus quantities must be related to the total quantity received by the client. If the client pays for 100 units and receives an additional 40 bonus units, the percentage that is equivalent to the price discount must be calculated in view of the relation between the 40 bonus units and the total of 140 units received by the client-that is, $28.57 \%$. The relation between 40 bonus units and 100 sold units $(40 \%)$ does not express this equivalence accurately.

\section{RESULT CREATED BY THE BONUS DECISION}

A decision model that involves profitability at the product level aims to optimize the contribution margin of these products. When deciding upon the size of of a bonus to be conceded, the decision model is expressed as follows:

where:

$$
m c=(p v-c v) \cdot q v-(c v \cdot q b)
$$

$$
\begin{aligned}
& m c=\text { contribution margin; } \\
& p v=\text { product sales price; } \\
& c v=\text { variable product cost } \\
& q v=\text { quantity actually sold; } \\
& q b=\text { quantity granted as a bonus; } \\
& m c=\text { contribution margin }
\end{aligned}
$$

so that:

$$
\begin{aligned}
& m c=(\$ 100-\$ 20) .100 u-(\$ 20.40 u) \\
& m c=\$ 7,200
\end{aligned}
$$

\section{RESULT GENERATED BY THE SALES PRICE DISCOUNT DECISION}

The sales price discount decision model is expressed as follows:

where:

$$
m c=(p v-d e \cdot p v-c v) \cdot q v
$$


$m c=$ contribution margin;

$p v=$ product sales price;

$d e=$ discount percentage expressed in hundredths;

$c v=$ variable product cost;

so that:

$m c=(\$ 100-0,2857 . \$ 100-\$ 20) .140 \mathrm{u}$

$m c=\$ 7,200$

\section{DETERMINATION OF THE BONUS COST WITH A LIMITED PRODUCTION CAPACITY}

When constraints limit a company's production volume in relation to market demand, the financial sacrifice derived from each product unit given as a bonus corresponds to the sales price itself and not to the variable cost (as previously). Assuming that a company can manufacture 140 units in a given period, and assuming a market demand greater than this, adopting the bonus policy in quantities of $40 \%$ would produce the following result:

$$
\begin{aligned}
& m c=(p v-c v) \cdot q v-(c v \cdot q b) \\
& m c=(\$ 100-\$ 20) \cdot 100 u-(\$ 20.40 u) \\
& m c=\$ 7,200
\end{aligned}
$$

Considering the company's limited production capacity, it could sell the 100 product units without any need for a bonus policy. In this way, its result would be:

$$
\begin{aligned}
& m c=(p v-c v) \cdot q v \\
& m c=(\$ 100-\$ 20) .140 u \\
& m c=\$ 11,200
\end{aligned}
$$

It must be observed that the value of the difference between the contribution margins is $\$ 4,000$ ( $\$ 11,200-\$ 7,200)$ which, divided by the product quantities granted as a bonus, corresponds to the price of $\$ 100$. That is, when the company's capacity is limited, the cost of a bonus unit corresponds to the product's sales price itself and not to the variable cost of the product. In other words, in this case, the cost of the bonus units is the opportunity cost of lost sales - that is, $\$ 100$ per unit.

\section{PRICE DISCOUNT AND QUANTITY BONUS DECISIONS FOR THE PURCHASING COMPANY}

Considering the data from the example above, when purchasing with a quantity bonus, the actual unit cost for the client corresponds to the total cost paid divided by the total units received. The total cost corresponds to the total quantities purchased multiplied by the negotiated unit cost - that is, $100 \mathrm{u} . \$ 100 / \mathrm{u}=\$ 10,000$. The actual unit cost corresponds to $\$ 10,000 / 140 \mathrm{u}=\$ 71.43 / \mathrm{u}$.

In the case of a price discount purchase for the total amount of $\$ 10,000$, a discount of $28.57 \%$ would be deducted. Thus, the net cost would amount to $\$ 10,000-\$ 2,857=\$ 7,143$ that is, an actual unit cost of $\$ 71.43$, which corresponds to $\$ 7,143 / 100 \mathrm{u}$.

\section{SURVEY METHODOLOGY}


The research question put here is: How do the controllers and how do the commercial managers of industrial companies perceive the various aspects of the product quantity bonus decision?

This study was developed on the basis of data obtained from two independent surveys of 600 pre-selected companies from the following sectors: (i) beverages; (ii) food; (iii) tobacco; (iv) hygiene, cleaning, and cosmetics; (v) construction material; (vi) pharmaceuticals; and (vii) plastic and rubber. The database used was that of the Institute for Accounting, Actuarial and Financial Research Foundation (Fipecafi) - an entity that supports the Department of Accounting and Actuarial Science of University of São Paulo. This database is used by Melhores e Maiores - a survey of the best and biggest Brazilian companies by the Brazilian business magazine Exame.

In the first study, held during the first semester of 2002, questionnaires were sent to commercial managers of the 600 companies - of which 64 correctly answered questionnaires were used. In the second study, held during the second semester of 2002, the same questionnaires were sent to the controllers of the same companies - of which the data from 91 correctly answered questionnaires were used. The questionnaire is presented in Attachment 1.

\section{RESULTS}

The results of the surveys are presented below. It should be noted that fourteen companies are part of both samples.

\begin{tabular}{lccc}
\hline \multicolumn{1}{c}{$\begin{array}{c}\text { TABLE 1 } \\
\text { Commercial strategies }\end{array}$} & $\begin{array}{c}\text { Controllers } \\
\text { (91 answers) }\end{array}$ & & $\begin{array}{c}\text { Commercial } \\
\text { managers } \\
(\mathbf{6 4} \text { answers) }\end{array}$ \\
\cline { 2 - 2 } $\begin{array}{lcc}\text { 1. Adopt both price discount and product quantity } \\
\text { bonus }\end{array}$ & $50.5 \%$ & $73.4 \%$ \\
2. Adopt only price discount & $35.2 \%$ & $17.2 \%$ \\
3. Adopt only product quantity bonus & $8.8 \%$ & $6.3 \%$ \\
4. Do not adopt either of these strategies & $5.5 \%$ & $3.1 \%$ \\
\hline
\end{tabular}

With respect to the strategies used by the companies, the data from both samples indicate that the majority of the companies adopted the price discount and the product quantity bonus. It must be observed that this answer was especially significant in the sample of commercial managers (73.4\%), and that few companies adopted only the product bonus strategy.

\section{TABLE 2}

Who decides about the kind of discount?

\begin{tabular}{|c|c|c|}
\hline & $\begin{array}{c}\text { Controllers } \\
\text { (54 answers) }\end{array}$ & $\begin{array}{c}\text { Commercial } \\
\text { managers } \\
(51 \text { answers }) \\
\end{array}$ \\
\hline 1. Marketing & $55.6 \%$ & $78.4 \%$ \\
\hline 2. Marketing and Finance & $33.3 \%$ & $17.6 \%$ \\
\hline 3. Finance & $7.4 \%$ & $0.0 \%$ \\
\hline 4. Another department & $3.7 \%$ & $3.9 \%$ \\
\hline
\end{tabular}


In both sample groups of companies with a product quantity bonus policy, the Marketing department (which in this study covers all commercial company functions) stood out as the department responsible for deciding about quantity discount versus price discount in the majority of the companies. The controllers considered that the Financial department participated more actively in this decision than did the commercial managers.

\section{TABLE 3}

How is the product bonus strategy materialized?

was sold

2. Free quantities of a different product from the one that was sold

3. Adopt both strategies

\begin{tabular}{|c|c|}
\hline $\begin{array}{c}\text { Controllers } \\
\text { (54 answers) }\end{array}$ & $\begin{array}{c}\text { Commercial } \\
\text { managers } \\
(51 \text { answers) }\end{array}$ \\
\hline $33.3 \%$ & $33.3 \%$ \\
\hline $3.7 \%$ & $0.0 \%$ \\
\hline $63.0 \%$ & $66.7 \%$ \\
\hline
\end{tabular}

The most frequently used strategy in both samples took the form of free bonus quantities of the same product and free bonus quantities of a different product from the one that was sold.

\begin{tabular}{|c|c|c|}
\hline \multicolumn{3}{|c|}{$\begin{array}{c}\text { TABLE } 4 \\
\text { Physical bonus product volumes }\end{array}$} \\
\hline & $\begin{array}{c}\text { Controllers } \\
(52 \text { answers) }\end{array}$ & $\begin{array}{c}\text { Commercial } \\
\text { managers } \\
(51 \text { answers })\end{array}$ \\
\hline 1.Up to $5 \%$ of the sold product quantity & $82.7 \%$ & $62.7 \%$ \\
\hline 2. Between $6 \%$ and $10 \%$ & $17.3 \%$ & $29.4 \%$ \\
\hline 3. Between $11 \%$ and $20 \%$ & $0.0 \%$ & $5.9 \%$ \\
\hline 4. Between $21 \%$ and $40 \%$ & $0.0 \%$ & $2.0 \%$ \\
\hline
\end{tabular}

In both research groups, the relation between the bonus quantities and the sold quantities ranged from 0 to $5 \%$ in most of the companies.

\section{TABLE 5}

Objectives of the product bonus policy

\begin{tabular}{|c|c|c|}
\hline 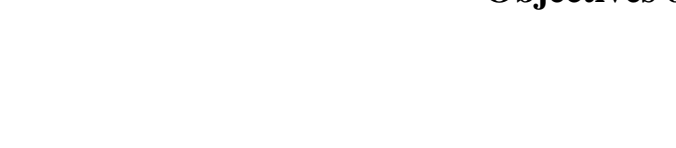 & $\begin{array}{c}\text { Controllers } \\
(52 \text { answers })\end{array}$ & $\begin{array}{c}\text { Commercial } \\
\text { managers } \\
\text { (51 answers) } \\
\end{array}$ \\
\hline $\begin{array}{l}\text { 1. Aggregate value to the sale and facilitate } \\
\text { negotiations with the client }\end{array}$ & $84.6 \%$ & $74.5 \%$ \\
\hline 2. Client loyalty & $82.7 \%$ & $68.7 \%$ \\
\hline 3. Increase in sales volume & $73.1 \%$ & $74.5 \%$ \\
\hline 4. Increase in market share & $67.3 \%$ & $64.7 \%$ \\
\hline 5. Brand fixing & $73.0 \%$ & $62.7 \%$ \\
\hline
\end{tabular}

Eleven objectives were presented to the marketing managers for their analysis, and the answers indicate that no single objective stood out. The results presented above represent the sum of two positive evaluation criteria ("fully agree" and "agree"), and highlight the five main objectives that were listed. 


\section{TABLE 6}

Main motive for granting a quantity bonus rather than a price discount

\begin{tabular}{|c|c|c|}
\hline & $\begin{array}{l}\text { Controllers } \\
(52 \text { answers })\end{array}$ & $\begin{array}{c}\text { Commercial } \\
\text { managers } \\
\text { (51 answers) }\end{array}$ \\
\hline $\begin{array}{l}\text { 1. A bigger product volume is brought onto the } \\
\text { market than in the case of the price discount }\end{array}$ & $50.0 \%$ & $49.0 \%$ \\
\hline $\begin{array}{l}\text { 2. The cost of the bonus concession is lower for the } \\
\text { company than the cost of the price discount }\end{array}$ & $26.9 \%$ & $33.3 \%$ \\
\hline $\begin{array}{l}\text { 3. The client considers bonus concession to be more } \\
\text { profitable than the discount }\end{array}$ & $13.5 \%$ & $9.8 \%$ \\
\hline 4. Other & $9.6 \%$ & $7.8 \%$ \\
\hline
\end{tabular}

With respect to the motives for using a quantity bonus policy instead of a price discount, the controllers and commercial managers held similar views. Among the motives that were listed for the company to use the quantity bonus policy instead of the price discount policy, most answers went to the motive: "a bigger product volume is brought onto the market than in the case of the price discount, which decreases the competitors' market shares". In second place was the motive: "for the company, the cost of the bonus concession is lower than the cost of the price discount". Few controllers and commercial managers thought the client considers bonus concession as more profitable than price discount. It is interesting that, for both managers, the client does not believe quantity bonus is more beneficial than price discount, although this policy is positive for the company since, in its opinion, the bonus cost is lower than the discount cost. As demonstrated in this study, the product bonus cost equals the discount cost, assuming that the client receives the same product volume in the end. Without this premise, the two commercial alternatives cannot be compared.

\section{TABLE 7}

Cost of product bonus units for the company

\begin{tabular}{|c|c|c|}
\hline & $\begin{array}{r}\text { Controllers } \\
(91 \text { answers }) \\
\end{array}$ & $\begin{array}{c}\text { Commercial } \\
\text { managers } \\
\text { (64 answers) }\end{array}$ \\
\hline $\begin{array}{l}\text { 1. Total manufacturing cost of the products (direct } \\
\text { material, labor, and indirect manufacturing spending) }\end{array}$ & $44.0 \%$ & $12.5 \%$ \\
\hline $\begin{array}{l}\text { 2. Total manufacturing cost plus expenses } \\
\text { (administrative, financial, and sales) }\end{array}$ & $26.4 \%$ & $54.7 \%$ \\
\hline $\begin{array}{l}\text { 3. Only the variable product cost (direct material and } \\
\text { direct labor) }\end{array}$ & $6.6 \%$ & $9.4 \%$ \\
\hline 4. Product sales price & $20.9 \%$ & $17.2 \%$ \\
\hline 5. Other & $2.2 \%$ & $6.3 \%$ \\
\hline
\end{tabular}

There was a marked discrepancy between the views of the controllers and those of the commercial managers in relation to the cost of the bonus units for the company. In the sample of controllers, $44 \%$ of 91 respondents believed that the cost of the bonus products is the total manufacturing cost (direct material, labor, and indirect manufacturing spending). In the 
sample of commercial managers, 54.7\% 91 respondents believed that the cost of bonus products is the total manufacturing cost (direct material, labor, and indirect manufacturing spending) plus expenses (administrative, financial, and sales). In conformity with the conceptual analysis, the product cost is its variable cost.

\section{TABLE 8}

How does the client see the economic benefit of the bonus units received?

. Total manufacturing cost of the products (direct

\begin{tabular}{ccc}
$\begin{array}{c}\text { Controllers } \\
(\mathbf{9 1} \text { answers })\end{array}$ & & $\begin{array}{c}\text { Commercial } \\
\text { managers } \\
(\mathbf{6 4} \text { answers })\end{array}$ \\
\cline { 1 - 1 } $31.0 \%$ & $9.4 \%$ \\
$3.3 \%$ & $9.4 \%$ \\
$5.5 \%$ & $1.6 \%$ \\
$80.2 \%$ & & \\
$0.0 \%$ & & $78.1 \%$ \\
& & $1.6 \%$ \\
\hline
\end{tabular}

The controllers and commercial managers held similar views with respect to how the client sees the economic benefit of the bonus units, which is the product sales price.

\section{Negative points of the product bonus policy}

The following alternatives were presented to the managers:

- there does not exist any relevant negative point;

- the negative point is that the product image is impaired in the market; or

- the negative point is that the product quantities granted as a bonus 'kill' future sales.

The controllers and commercial managers were of the opinion that there are no relevant negative points.

TABLE 9

Characteristics a product must possess to be the object of a bonus policy

\begin{tabular}{|c|c|c|}
\hline Characteristics a product must possess & $\begin{array}{l}\text { the object of a } \\
\text { Controllers } \\
\text { (91 answers) }\end{array}$ & $\begin{array}{l}\text { licy } \\
\text { Commercial } \\
\text { managers } \\
\text { (64 answers) }\end{array}$ \\
\hline 1. The product faces many competing products & $71.4 \%$ & $64.1 \%$ \\
\hline 2. Rapid consumption & $55.0 \%$ & $59.4 \%$ \\
\hline 3. Production capacity higher than the market demand & $48.4 \%$ & $60.9 \%$ \\
\hline
\end{tabular}

Taking the sum of the responses "fully agree" and "agree", the controllers and the commercial managers held similar views in relation to the characteristics that a product must possess to be the object of a bonus policy. The characteristic "the products faces many competing products" was the most popular for both groups of managers. With respect to the second most popular characteristic, the controllers indicated "rapid consumption" whereas the commercial managers indicated "production capacity higher than the market demand". 
TABLE 10

How does the company calculate product costs?

1. Using total manufacturing cost (legal/fiscal costing)

2. Using total cost (that is, apart from the manufacturing cost, administrative, commercial and financial expenses are allocated to the products)

3 . Using variable costing (that is, only the cost of raw material and variable inputs are part of the product cost)

4. Using the cost of raw material, variable labor and inputs

5. ABC (activity-based costing)

6. Other

\begin{tabular}{|c|c|}
\hline $\begin{array}{c}\text { Controllers } \\
\text { (113 answers) }\end{array}$ & $\begin{array}{c}\text { Commercial } \\
\text { managers } \\
(82 \text { answers })\end{array}$ \\
\hline $44.3 \%$ & $18.1 \%$ \\
\hline $23.0 \%$ & $55.0 \%$ \\
\hline $6.2 \%$ & $9.8 \%$ \\
\hline $12.4 \%$ & $11.0 \%$ \\
\hline $14.1 \%$ & $2.4 \%$ \\
\hline $0.0 \%$ & $3.7 \%$ \\
\hline
\end{tabular}

For this question, more than one answer was allowed. The controllers and commercial managers held different views in relation to how the company calculates the product costs. Data from the controller sample indicate that a large proportion of the companies calculate the product cost by using the criterion of total manufacturing cost. The commercial managers indicated that, in most of the companies, the product cost is calculated by using the total manufacturing cost plus expenses. Given that the controllers are responsible for this calculation, the commercial managers misunderstood this matter. The data obtained from the sample of controllers are in accordance with a study performed by Guerreiro, Catelli and Santos (2001) — which demonstrated that Brazilian companies calculate product cost according to the total manufacturing cost criterion (absorption costing).

\section{CONCLUSION}

The theoretical basis that was presented in this study demonstrates that the bonus product cost corresponds to the variable cost. Thus, there could be a tendency to believe that, from the point of view of company, a bonus policy would be better than a price discount policy. The theoretical arguments demonstrate that the economic results of both policies are equal. For this purpose, the bonus percentage and the price discount percentage must be equivalent.

The study demonstrates that most of the companies that made up the sample adopt a product quantity bonus policy together with a price discount policy. An insignificant number of companies adopts only a quantity bonus policy or only a price discount policy (or neither of these two policies).

In the companies that were part of the research, a decision on the type of policy is usually taken by the Marketing department, with some participation by the Financial department in certain companies. It is interesting to observe that, in the study of the controllers, the Financial department was perceived to play a greater part in the decisionmaking the decision alone (in $7.4 \%$ of responses) or together with the Marketing department $(33.3 \%)$. In contrast, the study of the commercial managers did not indicate any company in 
which the Financial department was perceived to take this decision individually, and the involvement of both Finance and Marketing appeared in only $17.6 \%$ of the companies.

In the majority of the companies (more than 63\%), the bonus strategy involves the delivery of a free quantity of the same product as well as a free quantity of a different product. However, a significant proportion of the companies (33.3\%) use only the same product.

It can be observed that the bonus product volume in relation to the total amount of sold products is not very high. In most cases, the bonus ranges from 0 to $5 \%$ of the sales.

Through a policy of product bonus quantity, companies seek to reach various objectives simultaneously — all of which are considered equally important. These include:

(i) increased value to the sale and facilitation of negotiations with the client;

(ii) increased sales volume during the period;

(iii) client loyalty;

(iv) increased market share; and

(v) brand fixing.

For the controllers and the commercial managers, the main motive was alternative (i) above.

The controllers and commercial managers also agree that the main motive that makes companies adopt the quantity bonus policy as an alternative to the price discount policy is that a bigger product volume is brought onto the market than in the case of the price discount (thus decreasing competitors' market shares). A second motive perceived by the controllers and the commercial managers is that the cost of the bonus concession for the company is lower than the cost of the price discount. Considering the theoretical foundations provided in this study, this perception is not correct. It was demonstrated that, assuming that an equal product volume is delivered to the client, the result of the quantity bonus decision and the result of the price discount decision are exactly equal.

A large proportion of the controllers and the commercial managers think the client does not perceive the benefit of the bonus as being more favorable than the benefit of the price discount. In contrast, almost $80 \%$ of the respondents believe that the client perceives the economic benefit of the bonus units as being the sales price of the received products. This perception seems to be technically correct since, without knowing the production cost of the bonus units received, the client must evaluate them in view of the sales price of the purchased units.

The controllers and commercial managers hold similar views about the main characteristics that a product must possess to be the object of a quantity bonus policy. The main characteristic that was indicated is that the product faces many competing products. The controllers and commercial managers also have the same view about the negative points of the product bonus policy. There does not exist a consensus among these managers in relation to the negative points, in that none of the alternatives was considered important.

The controllers and the commercial managers disagree with respect to how the company calculates the product cost. This question allowed for more than one answer. According to the controllers, in most of the companies, the method is "using the total manufacturing cost of the product". According to the commercial managers, the method that stands out is "using the total cost - that is, apart from the manufacturing cost, the administrative, commercial and financial expenses are allocated to the products". In view of the fact that the controllers are responsible for the product costing activity, in the majority of the companies, commercial managers hold an incorrect view of how the product costs are calculated.

\section{APPENDIX A}

BBR, Braz. Bus. Rev. (Eng. ed., Online), 


\section{Questionnaire}

1. Which commercial strategies does your company adopt with respect to discount (one single answer):

- (a) only a discount on the value of the product sales price;

- (b) only grants a product quantity bonus;

- (c) adopts both strategies;

- (d) does not adopt any of these strategies.

If you answered (a) or (d) to the first question, move on to Question 7.

2. In your company, which department decides about quantity discount 'versus' price discount (one single answer):

- (a) marketing;

- (b) finance;

- (c) both departments;

- (d) another department (please specify):

3. In your company, the product quantity bonus strategy is materialized (one single answer):

- (a) through free quantities of the same product that is being sold;

- (b) through free quantities of a different product than the product that is being sold;

- (c) adopts both strategies.

The following three questions $(4,5$, and 6) should be answered only if your company (even if partially) adopts a bonus policy using quantities of the same product.

4. In the case of products that are the object of a bonus policy, the physical volume of the product that was delivered as a bonus represented:

- (a) up to $5 \%$ of the billed product quantity;

- (b) between $6 \%$ and $10 \%$;

- (c) between $11 \%$ and $20 \%$;

- (d) between $21 \%$ and $40 \%$;

- (e) above $40 \%$.

5. Provide responses of 1 to 5 to each of the objectives the company intends to reach by its product bonus policy (according to the following criteria):

5 = fully agree; 4 = agree; $3=$ neither agree nor disagree; $2=$ disagree; $1=$ completely disagree.

- (a) increase in market share;

- (b) increase in sales volume during a specific period;

- (c) increase in profit during the specific period;

- (d) cost reduction;

- (e) client loyalty;

- (f) brand fixing;

- (g) release of excessive inventory;

- (h) rapid sale of products with an upcoming maturity date;

- (i) preserving the image of the sold product;

- (j) aggregate value to the sale and facilitate negotiations with theclient;

- (k) other (please specify):

6. What is the main motive for the concession of a product unit bonus instead of a price discount by your company (one single answer): 
- (a) for the company, the cost of the bonus concession is lower than the cost of the price discount;

- (b) the client perceives the bonus as being more favorable than the price discount;

- (c) a bigger product volume is brought onto the market than in the case of the price discount - thus decreasing the competitors' market shares;

- (d) other (please specify):

7. In your perception, the 'cost' of the product units granted as a bonus for the company is (one single answer):

- (a) total manufacturing cost of the products (direct material, labor and indirect manufacturing costs);

- (b) total manufacturing cost plus expenses (administrative, financial and sales);

- (c) only the variable product cost (direct material and direct labor);

- (d) the product's sales price;

- (e) other (please specify):

8. In your opinion, the client sees the value of the 'economic benefit' of the units received as a bonus as (one single answer):

- (a) total manufacturing cost of the products received;

- (b) total manufacturing cost plus expenses of the products received;

- (c) only the variable cost of the products received;

- (d) the sales price of the products received;

- (e) other (please specify):

9. Provide responses of 1 to 5 to the negative aspects of using a product bonus policy, according to the following criteria:

$5=$ fully agree; $4=$ agree; $3=$ neither agree nor disagree; $2=$ disagree; $1=$ completely disagree.

- (a) there does not exist any relevant negative point;

- (b) the negative point is that the product image is impaired in the market;

- (c) the negative point is that the product quantities granted as a bonus 'kill'future sales;

- (d) other ( please specify):

10. Provide responses of 1 to 5 to the characteristics that a product must possess to be the object of a bonus policy, according to the following criteria:

5 = fully agree; $4=$ agree; $3=$ neither agree nor disagree; $2=$ disagree $; 1=$ completely disagree.

- (a) rapid consumption;

- (b) production capacity higher than the market demand;

- (c) low total unit production cost;

- (d) low variable unit production cost;

- (e) the product faces many competing products;

- (f) the product has a small profitability margin;

- (g) clients are not loyal to the product;

- (h) other ( please specify):

11. The company calculates the product costs as follows (multiple answers are allowed):

- (a) by the manufacturing cost of the product-legal/fiscal costing;

- (b) by the total cost - that is, apart from the manufacturing cost, administrative, commercial and financial expenses are allocated to the products; 
- (c) by variable costing - that is, the product cost is only made up by raw materials and variable inputs;

- (d) by the cost of raw material, direct labor, and variable inputs;

- (e) ABC-activity-based costing;

- (f) another method (please specify):

\section{REFERENCES}

Aguirre, M. S.; Saidi, R. Evidence of forward discount determinants and volatility behavior. Journal of Economics Studies. vol. 25, n. 6, p. 538-552, 1998.

Arcelus, F.J.; Shah, Nita H.; Srinivasan G. Retailers's response to special sales : price discount vs. trade credit. Omega, volume 29, issue 5, p. 417-428, 2001.

Farhamgmher, M.; Brito, P. Q. As promoções de venda: definições, teoria e a percepção dos gestores. Revista Portuguesa de Marketing, ano 1, número 4, p. 35-42, 1997.

Friedman, H. H.; Lewis, B. J. Dynamic pricing strategies for maximizing customer satisfaction. The National Public Accountant, volume 44, issue 1, p. 8-9, 1999.

Goldratt, E. M. A Síndrome do palheiro: Garimpando informação num oceano de dados. São Paulo, Educator, 1992.

Guerreiro, R.; Angelo, C. F. Modelo de decisão de preços e rentabilidade sob a base conceitual de gestão econômica (Gecon). São Paulo, Revista de Contabilidade do CRC$S P$, p. 34-42, junho, 1999.

; Catelli, A.; Santos, A. Uma análise crítica da variação mista. In: VII Congresso Internacional de Custos, 2001, Leon, Espanha.

; Santos, A.; Gisbrescht, J. A S.; Ong, B. S. Cost implications of bônus pack promotions versus price discounts. American Business Review, Jun. 2004, 22, 2, p.72, 2004

Gurnani, H. A study of quantity discount pricing models with different ordering structures: order coordination, order consolidation, and multi-tier ordering hierarchy. International Journal of Production Economics, volume 72, issue 3, p. 203-225, 2001.

Horngren, C. T. Cost accounting: a managerial emphasis. New Jersey, Prentice-Hall, Inc. Englewood Cliffs, $3^{\mathrm{a}}$ ed., 1972.

Johnson, M. D.; Herrmann, A.; Bauer, H. H. The effects of price bundling on consumer evaluations of product offerings. International Journal of Research in Marketing, volume 16, issue 2, p. 129-142, 1999.

Kass, P. The rise of discount: How to survive the profit squeeze. British Food Journal, volume 96, number 2, p. 18-32, 1994.

Kopalle, P. K.; Mela, C. F.; Marsh, L. The dynamic effect of discounting on sales: empirical analysis and normative pricing implications. Marketing Science, volume 18, issue 3, p. 317-332, 1999.

Martins, E. Contabilidade de custos. São Paulo, Atlas, 9a . ed., 2003.

Monroe, K. B.; Cox, J. L. Pricing practices that endanger profits. Marketing Management, volume 10, issue 3, p. 42-46, 2001.

Munger, J. L.; Grewal, D. The effects of alternative price promotional methods on consumers` product evaluation and purchase intentions. Journal of Product and Brand Management. volume 10, number 3, p. 185-197, 2001. 
Noreen, E.; Smith, D.; Mackey, J. T. The theory of constraints and its implications for management accounting. Great Barrington, The North River Press Publishing Corporation, 1995.

Ong, B. S.; Ho, F. N.; Tripp, C. Consumer perceptions of bonus packs: an exploratory analysis. Journal of Consumer Marketing, volume 14, number 2, p. 102-112, 1997.

Reiter, J. What a deal! More processors are using value-style packaging to gain a competitive edge. Dairy Foods Magazine, 95, 2, 62-5, 1994.

Seibert, L. J. What consumers think about bonus pack sales promotions. Marketing News, February 17, vol. 31, issue 4, p.9, 1997.

Smith, M. F; Sinha, I. The impact of price and extra product promotions on store preference. International Journal of Retail and Distribution Management, vol. 28, issue 2, p. 83-92, 2000 . 